\title{
Geology and taphonomy of the base of the Taquaral Member, Irati Formation (Permian, Paraná Basin), Brazil
}

\author{
ARTUR CHAHUD*AND SETEMBRINO PETRI \\ Universidade de São Paulo, Instituto de Geociências, Departamento de Geologia Sedimentar e Ambiental. \\ Rua do Lago, 562. Cidade Universitária 05508-080 - São Paulo, SP - Brazil. \\ *E-mail address: arturchahud@yahoo.com
}

\begin{abstract}
Chahud, A. and Petri, S. 2015. Geology and taphonomy of the base of the Taquaral Member, Irati Formation (Permian, Paraná Basin), Brazil Acta Geologica Polonica, 65 (3), 379-387. Warszawa.

The taphonomy of Early Permian vertebrates from a sandy facies at the base of the Taquaral Member, Irati Formation, was surveyed in order to acquire data for the interpretation of the sedimentary processes and paleoenvironment of deposition. Six outcrops from the Rio Claro municipality and surrounding areas, from the Brazilian State of São Paulo, were investigated. The vertebrate groups are Chondrichthyes (Xenacanthiformes, Ctenacanthiformes and Petalodontiformes), Osteichthyes (Actinopterygii and Sarcopterygii) and Tetrapodomorpha. They occur as loose teeth, scales, spines and bone remains. The sandy facies is characterized by fining upward deposition. The coarser sandstone immediately above the underlying Tatuí Formation is rich in Chondrichthyes. However, the fine sandstone above, immediately beneath the silty shale facies, is devoid of Chondrichthyes, though Osteichthyes scales, teeth and bones were present. The taphonomy is important for inferring sedimentary processes and then the paleoenvironments. The poor sorting of the sandstone and the presence of fossils that are mostly abraded or worn are indicative of a high energy environment. In contrast, the presence of fossils in a good state of preservation, some without abrasion and breakages are indicative of only limited transport. Differences of fossil spatial density, numbers of specimens and taxa may be explained by the dynamics of deposition, from details of the palaeoenvironment can be obtained.
\end{abstract}

Keywords: Taphonomy; Permian; Actinopterygii; Sarcopterygii; Chondrichthyes.

\section{INTRODUCTION}

Ordovician to Cretaceous deposits from the southern Brazil intracratonic Paraná basin are grouped into several stratigraphic sequences. The thickest are Late Palaeozoic in age, of which the Irati Formation, Permian Cisuralian (Santos et al. 2006), is the most outstanding marker of changes in the tectonic behaviour of the basin (Milani and De Wit 2008). Two members of this formation were proposed by Barbosa and
Gomes (1958), the Taquaral Member at the base, succeeded by the Assistência Member.

The Taquaral is represented by two facies, the sandy facies, mostly located at the base, and silty-shale. The silty shale facies is thicker ( 5 to $30 \mathrm{~m}$ ) more homogeneous and more widespread than the sandy facies. Crustaceans and fish remains as the only fossils recovered from this facies (Chahud and Petri 2013a, 2013b).

The sandy facies consists of fine- to coarse-grained sandstones, with beds $5-50 \mathrm{~cm}$ thick. These beds are 
rich in fossils, teeth, scales and other vertebrates remains (Chahud and Petri 2008b, 2009, 2010a, 2012, 2014; Chahud et al. 2010), with different preservations, which may be caused by different types of depositional events.

The objective of this contribution is to disclose, for the first time, the taphonomies of the fossils from the sandy facies of the Taquaral Member and their contributions for a better understanding of the palaeoenvironments of the deposits.

\section{MATERIAL AND METHODS}

Most samples in the sandy facies came from six outcrops around Rio Claro municipality, State of São Paulo, Brazil (Text-figs 1-3). The fossils are Chondrichthyes scales, teeth and indeterminate bone remains.

Sedimentological and granulometric features and sedimentary structures were investigated as well as the total studied area of exposure, expressed in $\mathrm{m}^{2}$.

The numbers of fossils and their spatial density in relation to the area of accumulation $\left(\mathrm{N} / \mathrm{m}^{2}\right)$ were studied herein. The fossils may be crowded or scattered, the bioclasts touching each other or separated by matrix. Three degrees of packing, after Kidwell

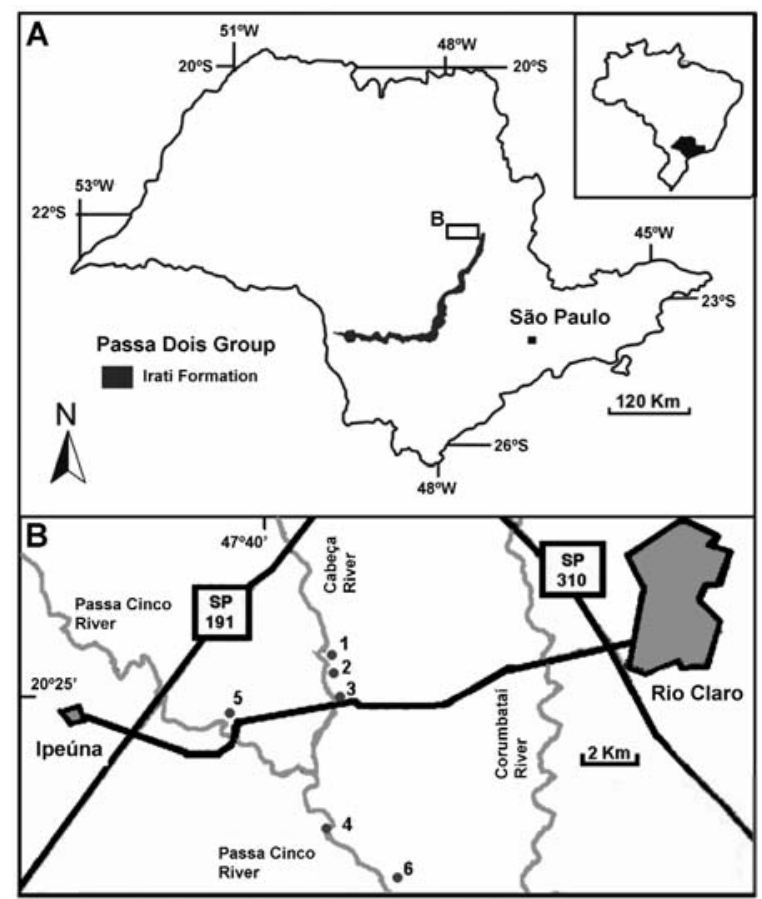

Text-fig. 1. A- Occurrence of the Irati Formation outcrops in the State of São Paulo. B - Region of Rio Claro with the locations of the outcrops studied ; 1-2) Santa Maria Homestead outcrops; 3) Cabeça River outcrop; 4) Bridge over Passa Cinco River outcrop; 5) Ponte Nova Farm outcrop; 6) outcrop near Passa Cinco River and Holland (1991) were considered: 1) densely packed; 2) loosely packed; 3) scattered distributed on plan observation.

The spatial position of the fossils gives clues to their dispositions along the strata (Behrensmeyer and Kidwell 1985; Behrensmeyer 1990, 1991). In plan view the fossils are either oriented or chaotic. In profile view, they are either parallel or discordant to the bedding. The fossils also may be crowded together or sparsely distributed. The orientation of the bioclasts in plan view may give clues to the depositional dynamic of the flows (palaeocurrents) (Behrensmeyer 1982, 1988, 1990, 1991; Elder and Smith 1988; Mancuso 2003, 2012; Fitzgerald et al. 2012)

The taphonomic study included breakages, abrasions, number of articulated pieces and size sorting. The sorting is significant for inferences of the depositional environment (Kidwell and Holland 1991; Mancuso 2003, 2012; Fitzgerald et al. 2012).

The concept of articulation, in the sense of Behrensmeyer (1991), includes articulated fossil, disarticulated fossil remains of the same specimen (association) and loose pieces and dispersed pieces.

The number of twenty samples per fossiliferous outcrop, collected for picking out the fossils in the laboratory, was arrived at through a test experiment, which demonstrated that 20 samples, containing more than two fossils per sample, were sufficient for calculating spatial density, the presence or absence of aggregates and the degree of sorting of the fossils.

Aliquots of each sample, $1 \mathrm{~cm}^{2}$ in size, were analyzed in order to obtain fossil arrangement and spatial density data. Only fossils over $0.5 \mathrm{~mm}$ long were selected because smaller inorganic pieces may be hard to distinguish from similar organic pieces.

The described and illustrated specimens were registered (GP/2E and GP/2T) at the Scientific Collections of the Systematic Paleontology Laboratory (LPS) of The Institute of Geosciences of the University of São Paulo.

\section{TAPHONOMIC CHARACTERISTICS}

\section{Santa Maria Homestead outcrops (1 and 2)}

Two outcrops of the Taquaral Member are present in Santa Maria Homestead, named outcrops 1 (UTM: 23K 227055/7517325) and 2 (UTM: 23K 227050/7517669). They are $190 \mathrm{~m}$ apart, so they exhibit similar sedimentological and palaeontological characteristics. Fine to medium sandstones with granules and a few millimetric pebbles, angular to rounded clasts, a few centimetres in 


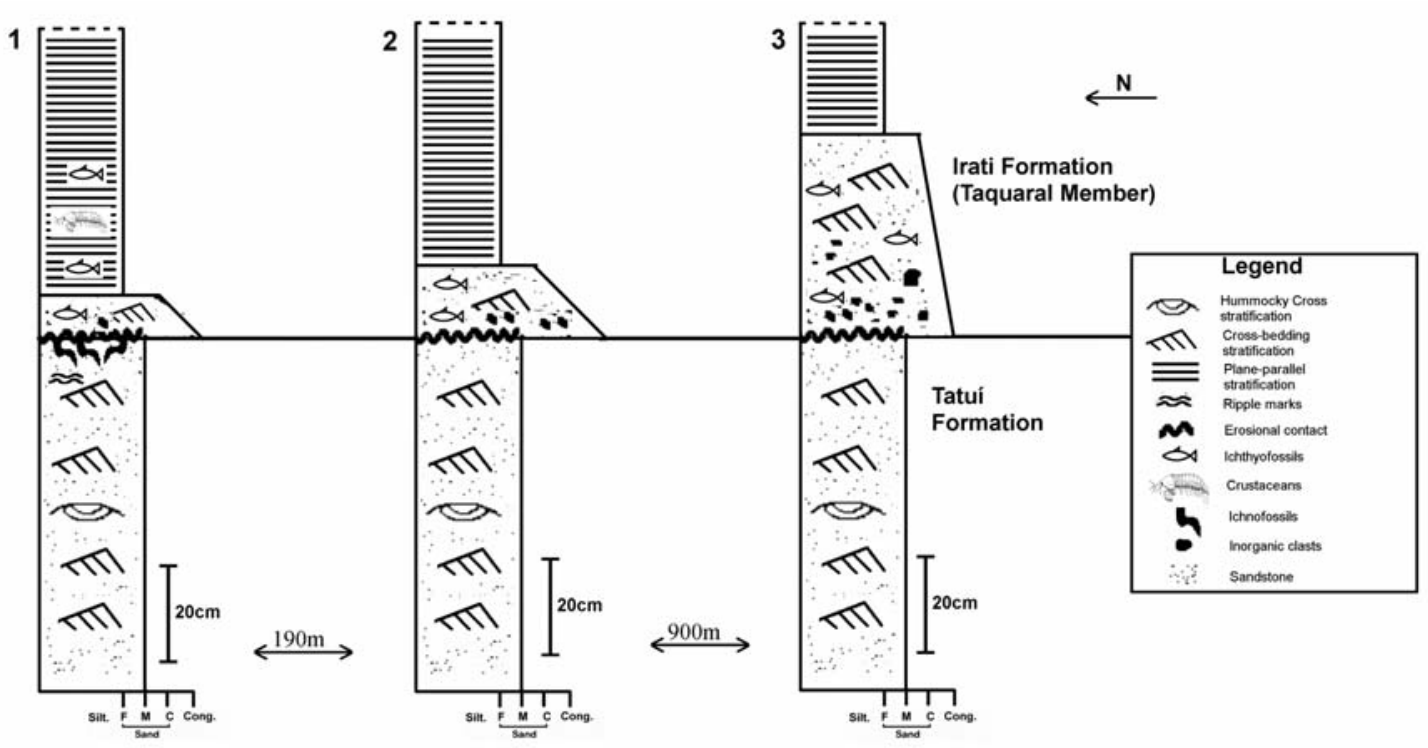

Text-fig. 2. Schematic logs. 1-2 - Santa Maria Homestead outcrops; 3 - Cabeça River outcrop

size, are present near the contact with the underlying Tatuí Formation beds.

The concentrated fossil assemblage layer of the Taquaral Member in outcrop 1 is exposed on a floor plan of $8 \times 20 \mathrm{~m}$ and in section, along a profile, 9.5 $\mathrm{cm}$ thick and $20 \mathrm{~m}$ long. The outcrop 2, a section in steps, is $40 \mathrm{~m}$ long, about $0.5 \mathrm{~m}$ wide and $15 \mathrm{~cm}$ thick.
In both outcrops the fossil spatial density is rather more than 1 fossil $/ \mathrm{cm}^{2}$, only fossils greater than 0.5 $\mathrm{mm}$ were studied. Similar to the inorganic clasts, they are matrix supported. However, isolated feeble crowding of groups of fossils seldom occurs, but not exceeding $0.5 \mathrm{~cm}^{2}$ per total area of the outcrop. In these cases the fossils are partially matrix supported.

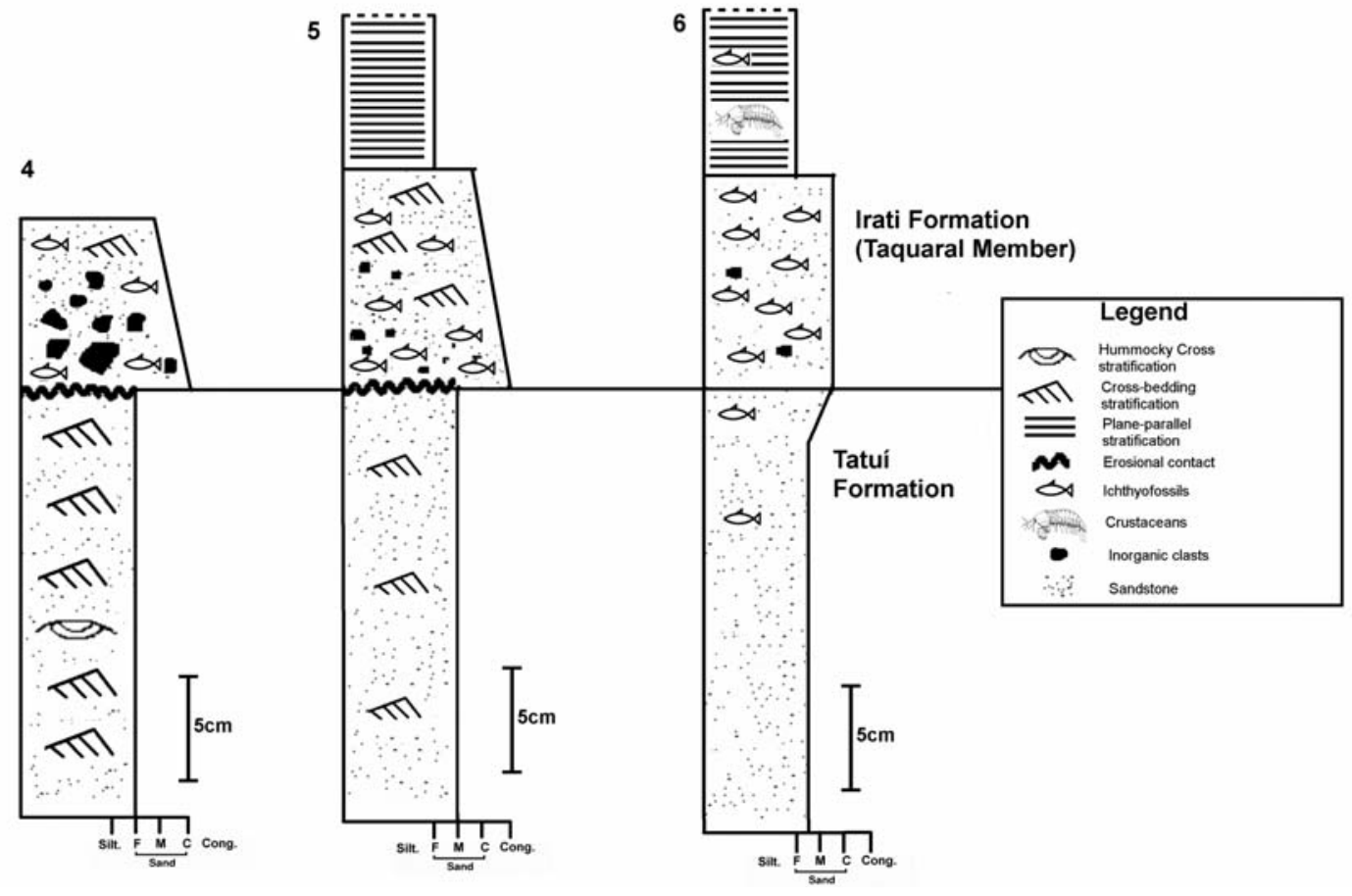

Text-fig. 3. Schematic logs. 4 - Bridge over Passa Cinco River outcrop; 5 - Ponte Nova Farm outcrop; 6 - outcrop near Passa Cinco River 


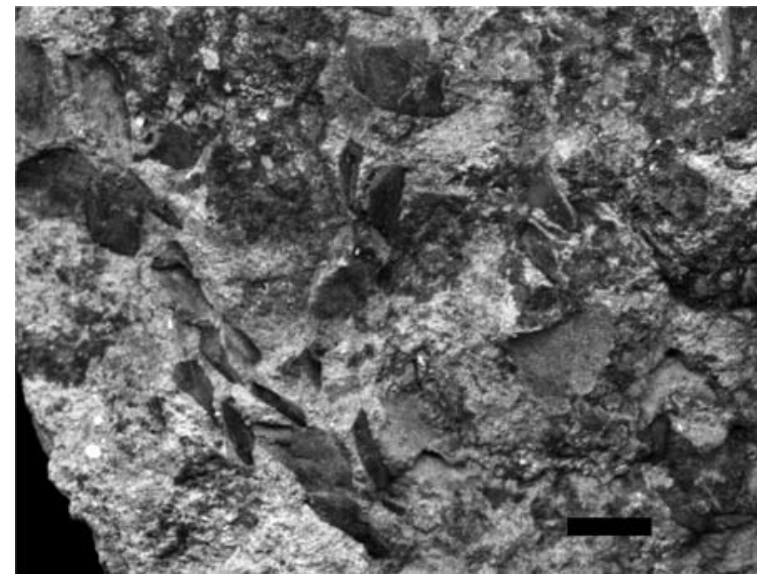

Text-fig. 4. View from above Palaeonisciformes scales. Evidence of accumulation. Santa Maria Homestead outcrop 1 (GP/2E-6383). Bar-scale: $1 \mathrm{~cm}$

No Chondrichthyes were observed at the sandy facies upper contact with the silty-shale facies but bone fragments, teeth and scales of Osteichthyes are widely dispersed.

At outcrop 1, the fossils, mostly Palaeonisciformes teeth and scales, do not exhibit any orientation in plan view; however, they are oriented concordantly to the bedding, even in cross bedding structures.

Aggregates and small accumulations of fossils are rare. The bioclasts are fragmented, smaller than $0.5 \mathrm{~cm}$.

Two examples of articulation are illustrated; a mandible with articulated teeth (see Chahud and Petri 2010a; figs 4, 6) and disarticulated Palaeonisciformes scales which must be from the same specimen, suddenly fallen to the bottom of the water body and immediately fossilized when disintegration started. The specimen GP/2E-6383 is specially noteworthy by the size of the scales, near $1 \mathrm{~cm}$. Probably they would belong to a large fish, articulated at the moment of deposition (Text-fig. 4).

The composition of the material is polytypic, consisting of scales, teeth, spines, bones and coprolites, and polyspecific, different species of Chondrichthyes and Osteichthyes. The number of taxa identified in outcrop 1 is higher than any other studied outcrop, including animals of continental origin (Tetrapoda), freshwater (Rhipidistias and Xenacanthidae) and salt water (Petalodontiformes and Diplodoselachidae).

Tetrapoda, cladodont teeth and Orodontiformes were not reported at outcrop 2; in any case, these fossils are scarce at outcrop 1. Only commoner forms of Petalodontiformes (Itapyrodus punctatus) and Diplodoselachidae (Taquaralodus albuquerquei) are present in outcrop 2.
The wide size range of bioclasts and fossils, from below $0.5 \mathrm{~mm}$ to more than $10 \mathrm{~mm}$, are neither related to taxa nor to their stratigraphic position, evidence of the total absence of sorting.

Many fossils, such as spines (Chahud et al. 2010) and cuspidate and ornamented Ctenacanthiformes teeth (Text-fig. 5A) are well preserved, only slightly abraded. Other fossils, such as Petalodontiformes (Text-fig. 5B), Xenacanthiformes and great Palaeonisciformes scales (Text-figs 5C-F), are strongly abraded. The degree of abrasion is related neither to the size of the fossils nor to the taxa.

\section{Cabeça River, limit between Rio Claro and Ipeúna municipalities (outcrop 3)}

This outcrop, located south of 1 and 2 (UTM: $23 \mathrm{~K}$ $227300 / 7517325)$, is similar to them, in terms of both lithology and palaeontological content. However, the frequency of fossils is smaller, scattered along the outcrop, even though distributed along a thicker exposure. The outcrop is $5 \mathrm{~m}$ long and $43 \mathrm{~cm}$ thick. The bed strikes $\mathrm{N} 45^{\circ} \mathrm{W}$, dipping $10^{\circ} \mathrm{NE}$, a dip greater than that of the other outcrops, which are less than $3^{\circ}$.

The fossil spatial density of this outcrop is about 0.5 fossil $/ \mathrm{cm}^{2}$. Viewed from above, no predominant fossil orientation is seen. In profile view most teeth and spines are parallel to the bedding; very few are discordant to the bedding. No aggregation were observed, compared with the previous discussed outcrops. The assemblage is polytypic with scales, teeth and bone fragments and polyspecific even though the specimens of Chondrichthyes are smaller.

In spite of scattered, badly sorted and disarticulated fossils, there are complete pieces with only small breaks. However, there are many differently sized fragmented bones.

The Petalodontiformes, even rare in this outcrop, are rounded and so strongly abraded that details of the internal dentine are revealed. In contrast, some "Palaeonisciformes" scales and teeth are well preserved, together with polished and completely worn specimens. This is a good example of different degrees of preservation of specimens deposited together.

Only uncommon forms of Xenacanthidae were found in this outcrop: two very worn and one in a better state of preservation (Chahud and Petri 2009). The Diplodoselachidae Taquaralodus (Chahud and Petri 2008a, 2010b) common in the other two outcrops, was not as yet found in this outcrop. This genus may be present here but the low spatial density renders it unsafe to infer its presence 
A

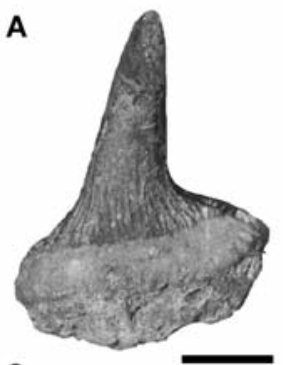

C

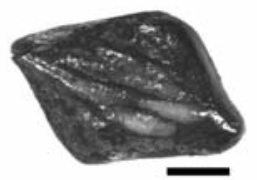

E

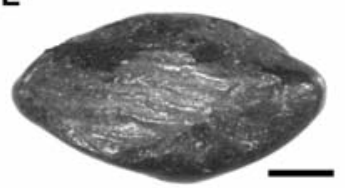

B

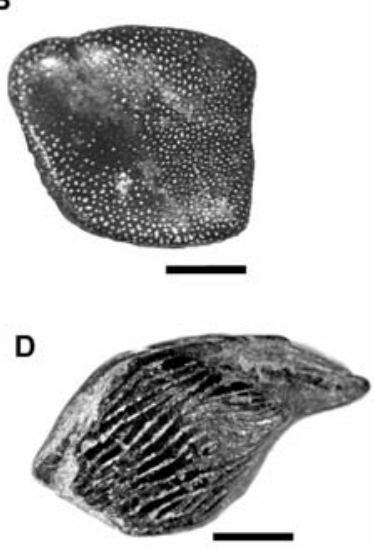

$\mathbf{F}$

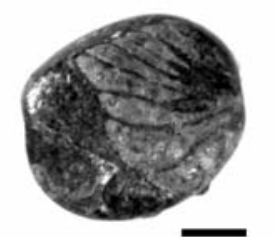

Text-fig. 5. Outcrop 1, sandy facies Taquaral Member ichthyofossils A - unweathered cladodont tooth (GP/2E-5919) with some matrix under it. Bar-scale $2 \mathrm{~mm}$. B - Itapyrodus punctatus tooth (GP/2T-206) with exposed dentine on the surface. Bar-scale 2mm; C-D - "Palaeonisciformes" scales (C: GP/2E-3758 and D: GP/2E-6577) with weakly abraded and ornate surfaces. Bar-scale $4 \mathrm{~mm}$ scale. E) Strongly abraded scale retaining some ornamentation, but loss of the original form (GP/2E-5960). Bar-scale: $2 \mathrm{~mm}$. F - "Palaeonisciformes" scale (GP/2E6463 ) highly abraded and worn with loss of the original shape. Bar-scale: $2 \mathrm{~mm}$

\section{Bridge over Passa Cinco River (outcrop 4)}

The bed in this outcrop is $8 \mathrm{~cm}$ thick and is split by the Passa Cinco river (UTM: 23K 227500/751345). The sedimentary structures are the same as those of the previously analyzed outcrops, but here larger clasts are more frequent, forming a poorly sorted matrix conglomerate at the base and a conglomeratic sandstone at the top.

The fossil spatial density is $0.1 / \mathrm{cm}^{2}$, the smallest index of all the outcrops analysed herein. No fossil over $0.5 \mathrm{~mm}$ were collected, only fragmented pieces. The fossils are scattered, no association of fossils are seen, no orientation trends are perceptible, no articulated pieces are seen; therefore, the numbers of fossils and taxa were the smallest of the outcrops studied.

The percentage of abraded and fragmented fossils is higher here than in the other outcrops. The abraded Petalodontiformes teeth exposed the tubular dentine, disclosing the punctuate surface. All indeterminate scales and possible tooth fragments are angular or worn completely smooth.
Most of the fossils exhibit breakages and abrasions; however, some specimens from several taxa are intact, with no evidence of reworking, like in the other above-mentioned outcrops.

\section{Ponte Nova Farm (outcrop 5)}

The sandy base of the Taquaral Member at the Ponte Nova Farm outcrop (UTM: 23K 0224255/ 7516138 ) is about $12 \mathrm{~cm}$ thick but the erosion along the outcrop resulted in variable thicknesses, with a minimum of $6 \mathrm{~cm}$.

The lithologies are badly sorted sandstones and conglomeratic sandstones, similar to the Santa Maria Homestead sandstones. However, close to the contact with the Tatuí Formation deposits, the sandstones are coarse to very coarse and the clasts and bioclasts become larger.

The fossil spatial density is similar to that at outcrop 1 , approximately $1 / \mathrm{cm}^{2}$ fossil, but the fossil distribution is different. They are not uniformly scattered but found together as small accumulations. The fossils are concentrated at the base, just above the Tatuí Formation.

Like other outcrops viewed from above, no fossil orientation is seen, whereas in profile view most of them are concordant with the bedding. Also, as in other outcrops, the taxonomic composition is polytypic, composed of scales, spines, bones, and polyspecific, with several Chondrichthyes, Taquaralodus albuquerquei, Itapyrodus punctatus and Amelacanthus sp. (Chahud et al. 2012; Chahud and Petri 2014) (Text-fig. 6A-G) and Osteichthyes.

Chondrichthyes and Osteichthyes are reported together in aggregates, resulting from accumulations of transported material.

No size sorting of the fossils is observed. The bioclasts range from $0.5 \mathrm{~mm}$ long to over $50 \mathrm{~mm}$. Many fossils, among them Palaeonisciformes scales, were strongly abraded and polished.

\section{Outcrop near Passa Cinco River (outcrop 6)}

This outcrop typically exposes fine sandstones with sparse $0.5 \mathrm{~mm}$ to $1 \mathrm{~mm}$ clasts, on both sides of a road to the Passa Cinco river (UTM: 23K 228537/7512610).

In contrast to the other outcrops studied, the fossils here are either scattered or more closely packed, with a density of over $10 / \mathrm{cm}^{2}$, so this outcrop is placed in the last column of Table 1. Viewed from above no fossil orientation is observed. In profile view many of the fossils are concordant with the bedding.. Some scales, teeth and bones are fragmented or comminuted. 
In spite of the high density of the fossils, neither taxon associations nor fossil articulations were observed. In contrast to the other outcrops, the fossils are well sorted, mostly similar in size.

Most fossils must have been destroyed by breakage as many of the bioclasts are angular and weakly polished.

\section{TAPHONOMIC RESULTS}

The lithologies and fossil associations of the outcrops 1 to 5 have the following common features: badly sorted lithologies; badly sorted fossil associations; bioclast fragmentation; very rare articulated fossils, intensive abrasion of scales and teeth and chaotic fossil disposition in plan view. These common characteristics indicate a common origin, a high energy environment.

Besides the reworked and fragmented fossils, others occur in a good state of preservation, such as teeth with no or very little abrasion or small breakages. These rare examples of fossils in a good state of preservation indicate little transport, small reworking or only a short residence in the Taphonomically Active Zone (TAZ) (Davies et al. 1989). The conjunction of evidence excludes the hypothesis of reworked ancient deposits.

The fossil spatial densities are larger at outcrops 1 and 2 and smaller at outcrop 4, the deposits of which are coarser. From outcrops 1 to 3, the thicknesses increase from $9.5 \mathrm{~cm}$ to $43 \mathrm{~cm}$ and the spatial densities decrease from $1 / \mathrm{cm}^{2}$ to $0.5 / \mathrm{cm}^{2}$.

These differences might be explained by an increase in distance from the sources of the sediments which were located to the south in the present day geography. Holz and Simões (2002) suggested that a long time of exposure results in a high spatial density and time averaging.

This southward transgression caused the fining-upward deposits, the fossil spatial density decrease from 1 to 4 and larger clasts at outcrop 4 .

Increase in water volume by transgression, together with reworking events during deposition, caused remobilization of the fine material, while the very coarse material, with granules and pebbles, remained, retaining the most resistant fossil pieces. This high energy paleoenvironment would be responsible for the small thicknesses, seldom reaching $1 \mathrm{~m}$ (Walker and James 1992; Holz and Simões 2002). A high degree of reworking mean that the fossils were submitted to extended activities of reworking and transportation.

According to Assine et al. (2003) the sandy facies was laid down under a lag process, which would mean
A
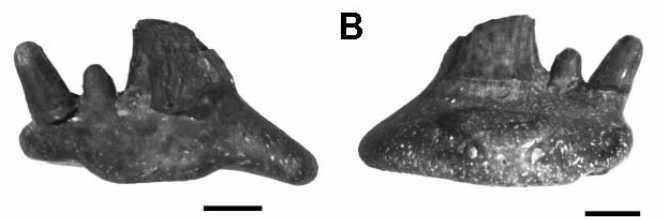

C

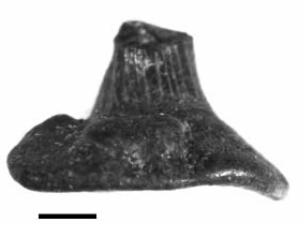

E

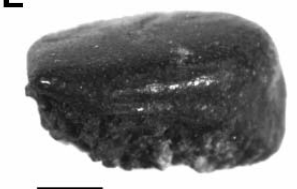

D

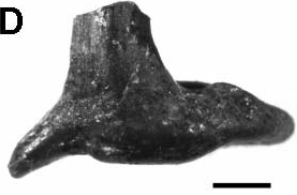

$\mathbf{F}$

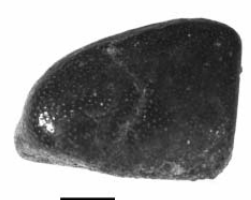

G

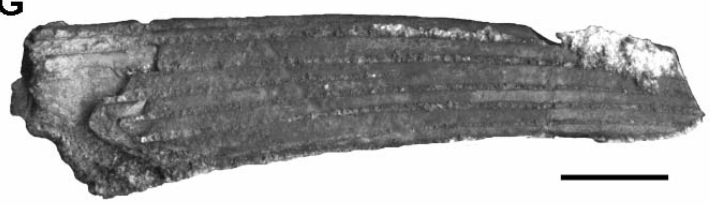

Text-fig. 6. Chondrichthyes from the Taquaral Member sandy facies at Ponte Nova Farm outcrop. A-D - Taquaralodus albuquerquei little worn teeth, but with broken cusps (A-B: GP/2E-6580 and C-D: GP/2E-6581). E-F - Itapyrodus punctatus (GP/2E-6589) little worn teeth. A-F Bar-scales $2 \mathrm{~mm}$. G-Amelacanthus sp. (GP/2E-6579) Spine with well preserved ribs. Bar-scale: $10 \mathrm{~mm}$

a continuous winnowing of fine deposits and coarser deposition. In this scenario good preservation of fragile fossils was not possible. The presence of thin laminae of siltstone interbedded with coarse sandy deposits and fragile fossils are better explained by short episodes of higher energy events.

The sharp contrast of good and bad preservations may be explained by two hypothesis (A and B). Both hypotheses could be true, depending on the outcrop studied. A) Swift episodic changes of energy of the palaeoenvironment increase wave reworking, transporting coarser material toward the larger water body. B) Rainy seasons caused the river to overflow into the large water body, increasing the bedload. So, increasing the bedload of the larger water body is the result of both hypotheses, favouring the preservation of fragile fossils.

Occasional fine sandstones and silty laminations are interbedded with coarser deposits. They occur mainly in Santa Maria Homestead outcrop 1; short intervals of low energy favoured fine laminations.

The increasing thicknesses of the outcrops 1 to 3 (Text-fig. 2) furnish important clues for understanding the episodes of the dynamics of sedimentation. These 
TAPHONOMY OF THE IRATI FORMATION, PERMIAN,BRAZIL

\begin{tabular}{|c|c|c|c|c|c|}
\hline $\begin{array}{l}\text { Data obtained / } \\
\text { Outcrops }\end{array}$ & $\begin{array}{c}\text { Santa Maria } \\
\text { Homestead outcrops } 1 \\
\text { and } 2 \\
\end{array}$ & $\begin{array}{c}\text { Cabeça River } \\
\text { Outcrop } 3\end{array}$ & $\begin{array}{c}\text { Bridge over Passa Cinco } \\
\text { River } \\
\text { Outcrop } 4 \\
\end{array}$ & $\begin{array}{c}\text { Ponte Nova Farm } \\
\text { Outcrop } 5\end{array}$ & $\begin{array}{c}\text { Outcrop near Passa } \\
\text { Cinco River } \\
\text { Outcrop } 6 \\
\end{array}$ \\
\hline $\begin{array}{l}\text { Sedimentologica } \\
1 \text { characteristics }\end{array}$ & $\begin{array}{c}\text { Fine to medium } \\
\text { sandstone or } \\
\text { conglomeratic. Some } \\
\text { centimetric clasts in } \\
\text { basal contact of the unit. }\end{array}$ & $\begin{array}{l}\text { Fine to medium } \\
\text { sandstone or } \\
\text { conglomeratic. } \\
\text { Some } \\
\text { centimetric } \\
\text { clasts in basal } \\
\text { contact of the } \\
\text { unit. }\end{array}$ & $\begin{array}{l}\text { Conglomerate with little } \\
\text { matrix. Some larger clasts } \\
\text { more abundant }\end{array}$ & $\begin{array}{l}\text { Fine- to medium- } \\
\text { grained sandstone } \\
\text { or conglomerates. } \\
\text { Some centimetric } \\
\text { clasts in basal } \\
\text { contact of the unit. }\end{array}$ & $\begin{array}{l}\text { fine sandstones with rare } \\
\text { clasts }\end{array}$ \\
\hline Bed thickness & $\begin{array}{l}9.5 \mathrm{~cm} \text { at Outcrop } 1 \\
15.0 \mathrm{~cm} \text { at Outcrop } 2\end{array}$ & $43.0 \mathrm{~cm}$ & $8.0 \mathrm{~cm}$ & $12.0 \mathrm{~cm}$ & $10.0 \mathrm{~cm}$ \\
\hline $\begin{array}{l}\text { Spatial density } \\
\text { Fossil } / \mathrm{cm}^{2}\end{array}$ & $\sim 1.0 / \mathrm{cm}^{2}$ & $\sim 0.5 / \mathrm{cm}^{2}$ & $\sim 0.1 / \mathrm{cm}^{2}$ & $\sim 1.0 / \mathrm{cm}^{2}$ & $\begin{array}{c}\text { Varies from weak to } \\
\text { strongly packaged } \\
\sim 10 / \mathrm{cm}^{2} \\
\end{array}$ \\
\hline $\begin{array}{c}\text { Spatial } \\
\text { arrangement in } \\
\text { plan view } \\
\end{array}$ & Random & Random & Random & Random & Random \\
\hline $\begin{array}{c}\text { Spatial } \\
\text { arrangement in } \\
\text { profile view }\end{array}$ & Generally concordant & $\begin{array}{c}\text { Generally } \\
\text { concordant }\end{array}$ & Generally concordant & $\begin{array}{l}\text { Generally } \\
\text { concordant }\end{array}$ & Random \\
\hline $\begin{array}{l}\text { Accumulations } \\
\text { and aggregates }\end{array}$ & $\begin{array}{c}\text { Rare (few occasional } \\
\text { accumulations) }\end{array}$ & Absent & Absent & $\begin{array}{l}\text { Present in fossils of } \\
\text { various sizes }\end{array}$ & $\begin{array}{c}\text { Occasional dense } \\
\text { concentrations }\end{array}$ \\
\hline $\begin{array}{l}\text { Chondrichthyes } \\
\text { rate number } \\
\text { (based on orders } \\
\text { and subclass) }\end{array}$ & $\begin{array}{c}5 \\
\text { Petalodontiformes, } \\
\text { Ctenacanthiformes, } \\
\text { cladodonts, } \\
\text { Xenacanthidae and } \\
\text { Diplodoselachidae } \\
\end{array}$ & $\begin{array}{c}2 \\
\text { Petalodontiform } \\
\text { es and } \\
\text { Xenacanthidae }\end{array}$ & $\begin{array}{c}1 \\
\text { Petalodontiformes }\end{array}$ & $\begin{array}{c}3 \\
\text { Petalodontiformes, } \\
\text { Ctenacanthiformes } \\
\text { and } \\
\text { Diplodoselachidae }\end{array}$ & Absent \\
\hline $\begin{array}{l}\text { Osteichthyes } \\
\text { rate number } \\
\text { (based on orders } \\
\text { and subclass) }\end{array}$ & $\begin{array}{c}4 \\
\text { Palaeonisciformes, } \\
\text { Coelacanthimorpha, } \\
\text { Osteolepimorpha and } \\
\text { Tetrapoda } \\
\end{array}$ & $\begin{array}{c}2 \\
\text { Palaeonisciform } \\
\text { es, and } \\
\text { Sarcopterygii } \\
\text { indeterminate } \\
\end{array}$ & $\begin{array}{c}2 \\
\text { Palaeonisciformes, and } \\
\text { Sarcopterygii indeterminate }\end{array}$ & $\begin{array}{c}4 \\
\text { Palaeonisciformes, } \\
\text { Coelacanthimorpha, } \\
\text { Osteolepimorpha } \\
\text { and Tetrapoda } \\
\end{array}$ & $\begin{array}{c}2 \\
\text { Palaeonisciformes and } \\
\text { Sarcopterygii } \\
\text { indeterminate }\end{array}$ \\
\hline Articulation & $\begin{array}{c}\text { Generally absent } \\
\text { (Only few articulated } \\
\text { teeth or associated } \\
\text { bones) }\end{array}$ & Absent & Absent & Absent & Absent \\
\hline $\begin{array}{l}\text { Bone parts } \\
\text { selection } \\
\text { (general } \\
\text { context) }\end{array}$ & $\begin{array}{l}\text { Bad (many fossils of } \\
\text { different sizes) }\end{array}$ & $\begin{array}{c}\text { Bad (many } \\
\text { fossils of } \\
\text { different sizes) }\end{array}$ & $\begin{array}{l}\text { Bad (many fossils of } \\
\text { different sizes) }\end{array}$ & $\begin{array}{l}\text { Bad (many fossils } \\
\text { of different sizes) }\end{array}$ & $\begin{array}{l}\text { Bad (many fossils of } \\
\text { different sizes) }\end{array}$ \\
\hline
\end{tabular}

Table 1. Comparison of outcrops studied to taphonomy

observations reinforce a scenario of river overflows, carrying great amount of detritus, including freshwater organisms, which were transported to a water body of variable salinity. The euryhaline fossils (Petalodontiformes, Diplodoselachidae) increase the fossil richness in deeper water palaeoenvironments.

Outcrop 3 (Cabeça River) is noteworthy because of its greatest thickness and low fossil density. The frequency of petalodonts is low, Diplodoselachidae Taquaralodus and spines are absent so far. Rare Xenacanthidae, which were probable inhabitants of freshwater palaeoenvironments, were also found (Table 1).

Better preserved larger fossils are always found in the coarser lithologies. These deposits might be laid down at the beginning of the transgressive event. Ragonha (1978) similarly observed it in the Assistência municipality (near Rio Claro), where these fossils were present only in coarser and badly sorted lithologies.

The Santa Maria Homestead outcrop 1 site would be the area of higher energy episode caused either by overflows or storms. The Cabeça River outcrop 3 site would be nearer the source area, and hence exhibiting higher thickness and smaller spatial density.

Outcrop 6 (Near Passa Cinco River) is unique in the studied region by the presence of millimetric, very fine sandstones and siltistones, interbedded with fine sandstone. The small clasts and millimetre-sized fossil fragments were dropped by decantation. The increased spatial density is caused by lightweight bioclasts as compared to heavier clasts. However, as the fossil fragments are small and reworked, their preservations are not good.

Table 1 synthesizes the similarities and the differences of the outcrop deposits and fossils. Their common char- 
acteristic is the intense abrasion and fragmentation of the fossils, which reinforce the palaeoenvironmental interpretation of a generalized high energy body of water.

\section{CONCLUSIONS}

Several sedimentological and palaeontological characteristics are common to the six outcrops: small thicknesses from $8 \mathrm{~cm}$ to $43 \mathrm{~cm}$, fining-upward deposition and poorly sorted conglomeratic sandstones and conglomerates. Only fine sandstone is present in outcrop 6 .

From a palaeontological point of view, the fossil spatial densities at the outcrops 1 to 5 vary from $1 / \mathrm{cm}^{2}$ to $0.5 / \mathrm{cm}^{2}$, seldom greater when locally the fossils are aggregated. There is no orientation of the fossils when observed from above but the fossils are concordant with the bedding in profile view. In outcrop 6 orientation of the fossils cannot be clearly seen because the fossils are completely comminuted.

The fossil contents are always vertebrates belonging to the following taxonomic groups: Chondrichthyes (Petalodontiformes, Ctenacanthiformes, cladodonts, Diplodoselachidae and Xenacanthidae), Actinopterygii (Palaeonisciformes) and Sarcopterygii (Coelacanthimorpha and Indeterminate Sarcopterygii) and tetrapods.

The Santa Maria Homestead Outcrop 1 is unique in that it shows an aggregate of bone remains packed together from a single specimen, which were disarticulated a short time before deposition, with the mandible still retaining articulated teeth (Chahud and Petri 2010a) and well preserved spines. The small degree or complete absence of breakage of the fossils and the association of fragments from a single specimen are suggestive of sudden death by overflows and storms with rather short transport.

The association, at several outcrops, of more frequent fragmented fossil remains and rare well preserved fossils without abrasions or breakages not related to specific taxa, is a highly significant relationship, suggesting different organisms episodically transported downstream during different overflow phases, with the possible addition of some storm episodes.

The Chondrichthyes are reported from the basal beds of the sandy facies, immediately above the Tatuí Formation deposits. They are absent in the fining-upward deposits. Furthermore, it is important to remember the absence of stenohaline fossils in the entire Taquaral Member (Mussa et al. 1980; Chahud and Petri 2013b). These observations enable the inference that no typical marine palaeoenvironments are repre- sented in the sediments of the Taquaral Member with the exception of the most basal beds of the sandy facies being of a transitional nature.

\section{Acknowledgements}

The authors thank the Conselho Nacional de Desenvolvimento Científico e Tecnológico (CNPq) (Grant: $500755 / 2013-2)$ for financial support; Prof. Dr. Thomas Rich Fairchild for support and jointing field researches, and the proprietors of the Santa Maria homestead, Luiz and Bernadete Esposti, and Ponte Nova Farm, Mr. Bartman. The authors thank also the Departamento de Geologia Sedimentar e Ambiental of the Institute of Geoscience of the University of São Paulo which allowed the preparation of fossils in its laboratories.

\section{REFERENCES}

Assine, M.L., Zacharias, A.A. and Perinotto, J.A.J. 2003. Paleocorrentes, paleogeografia e seqüências deposicionais da Formação Tatuí, centro-leste do Estado de São Paulo. Revista Brasileira de Geociências, 33, 33-40.

Barbosa, O. and Gomes, F.A. 1958. Pesquisa de petróleo na bacia do rio Corumbataí. Rio de Janeiro, Boletim do $D N P M / D G M, 171,1-40$.

Behrensmeyer, A.K. 1982. Time resolution in fluvial vertebrate assemblages. Paleobiology, 8, 211-227.

Behrensmeyer, A.K. 1988. Vertebrate preservation in fluvial channels. Palaeogeography, Palaeoclimatology, Palaeoecology, 63, 183-199.

Behrensmeyer, A.K. 1990. Bones/transport-hydrodynamics, In: D.E. Briggs and P.R. Crowther (Eds), Paleobiology: A Synthesis, pp. 232-235. Blackwell; Oxford.

Behrensmeyer, A.K. 1991. Terrestrial vertebrate accumulations. In: P.A. Allison and D.E. Briggs (Eds), Taphonomy: releasing the data locked in the fossil record, pp. 291-327. Plenum Press; New York.

Behrensmeyer, A.K. and Kidwell, S.M. 1985. Taphonomy's contributions to paleobiology, Paleobiology 11, 105-107

Chahud, A., Fairchild, T.R. and Petri, S. 2010. Chondrichthyans from the base of the Irati Formation (Permian, Parana Basin), São Paulo, Brazil. Gondwana Research, 18, 528-537.

Chahud, A., Pacheco, M.L.A.F., Meira, F.E., Romero, G.R. and Petri, S. 2012. Paleontology and depositional environments of the Tatuí and Irati formations (Permian) in the Ponte Nova Farm, Ipeúna, state of São Paulo. Revista Brasileira de Geociências, 42, 198-212.

Chahud, A. and Petri, S. 2008a. Chondrichthyes no Membro Taquaral, base da Formação Irati, no centro-leste do Es- 
TAPHONOMY OF THE IRATI FORMATION, PERMIAN,BRAZIL

tado de São Paulo, Brasil. Revista de Geologia. Fortaleza, 21, 169-179.

Chahud, A. and Petri, S. 2008b. Registro de Paleoniscóides na base do Membro Taquaral, Formação Irati, Permiano da Bacia do Paraná. Revista do Instituto Geológico. 29, 33-40.

Chahud, A. and Petri, S. 2009. Novos Xenacanthidae (Chondrichthyes, Elasmobranchii) da base do Membro Taquaral, Formação Irati, Permiano da Bacia do Paraná. Revista do Instituto Geológico, 30, 19-24.

Chahud, A. and Petri, S. 2010a. Anfíbio e Paleonisciformes da Porção Basal do Membro Taquaral, Formação Irati (Permiano), Estado de São Paulo, Brasil. Geologia USP. Série Científica. São Paulo, 10, 29-37.

Chahud, A. and Petri, S. 2010b. O tubarão Taquaralodus albuquerquei (Silva Santos, 1946) do Membro Taquaral (Permiano, Formação Irati) no Estado de São Paulo. Acta Biologica Paranaense, 39, 1-17.

Chahud, A. and Petri, S. 2012. Levantamento dos cladodontes sul-americanos e novos espécimes do Membro Taquaral (Formação Irati, Permiano), Bacia do Paraná. Boletim Paranaense de Geociencias, 66-67, 23-29.

Chahud, A. and Petri, S. 2013a. Paleontology of Taquaral Member silty shale in the State of São Paulo. Brazilian Journal of Geology, 43, 117-123.

Chahud, A. and Petri, S. 2013b. The silty shale Taquaral Member of the early Permian Irati Formation (Paraná Basin, Brazil). Paleontology and paleoenvironments. Swiss Journal of Palaeontology, 132, 119-128.

Chahud, A. and Petri, S. 2014. New chondrichthyans from the Irati Formation (Early Permian, Paraná Basin), Brazil: origin, paleoenvironmental and paleogeographical considerations. Proceedings of the Geologists' Association, 125, 437-445.

Davies, D.J., Powell, E.P. and Stanton, R.J., Jr. 1989. Relative rates of shell dissolution and net sediment accumulation-a commentary: Can shell beds form by the gradual accumulation of biogenic debris on the sea floor? Lethaia, 22, 207-212.

Elder, R.L. and Smith, G.R. 1988. Fish taphonomy and environmental inference in paleolimnology. Palaeogeography, Palaeoclimatology, Palaeoecology, 62, 577-592.
Fitzgerald, M.H., Simpson, E.L., Szajna, M.J., Fillmore, D. L., Hartline, B.W., Heness, E.A., Kraal, E.R. and Wilk, J.L. 2012. Taphonomy of lacustrine shoreline fish-part conglomerates in the Late Triassic age Lockatong Formation (Collegeville, Pennsylvania, USA): Toward the recognition of catastrophic fish kills in the rock record. Palaeogeography, Palaeoclimatology, Palaeoecology, 313-314, 234-245

Holz, M. and Simões M.G. 2002. Elementos Fundamentais de Tafonomia. pp. 231. Editora da Universidade/UFRGS Porto Alegre.

Kidwell, S.M. and Holland, S.M. 1991. Field description of course bioclastic fabrics. Palaios, 6, 426-434.

Mancuso, A.C. 2003. Continental fish taphonomy: a case study in the Triassic of Argentina. Journal of South American Earth Sciences, 16, 275-286.

Mancuso, A.C. 2012. Taphonomic analysis of fish in rift lacustrine systems: Environmental indicators and implications for fish speciation. Palaeogeography, Palaeoclimatology, Palaeoecology, 339-341, 121-131

Milani, J. and De Wit, M.J. 2008. Correlations between the classic Paraná and Cape-Karoo sequences of South America and southern Africa and their basin infills flanking the Gondwanides: du Toit revisited. Geological Society, London, Special Publications, 294, 319-342

Mussa, D. Carvalho, R.G. and Santos, P.R. 1980. Estudo estratigráfico e Paleoecológico em Ocorrências Fossilíferas da Formação Irati, Estado de São Paulo, Brasil. Boletim do IG/USP, 11, 31-189.

Ragonha, E.W. 1978. Chondrichthyes do Membro Taquaral (Formação Irati) no Estado de São Paulo. Master Dissertation. Instituto de Geociências, Universidade de São Paulo, São Paulo (unpublished).

Santos, R.V., Souza, P.A., Alvarenga, C.J.S., Dantas, E.L., Pimentel, E.L., Oliveira, C.G. and Araújo, L.M. 2006. Shrimp U-Pb zircon dating and palynology of bentonitic layers from the Permian Irati Formation Parana Basin, Brazil. Gondwana Research, 9, 456-463.

Walker, R.G. and James, N.P. 1992. Facies Models - response to sea level change. Geological Association of Canada, pp. 409. 